Studia Maritima, vol. XXXI (2018)

ISSN 0137-3587

DOI: $10.18276 / \mathrm{sm} .2018 .31-10$

Emilia Denkiewicz-Szczepaniak*

\title{
ESTABLISHING DIPLOMATIC RELATIONS BETWEEN POLAND AND NORWAY IN THE YEARS 1945-1946
}

Keywords: Polish-Norwegian relations, establishing diplomatic relations in the years 1945-1946, activity of diplomatic representatives of the Polish Government in Exile in Norway, taking over Polish Mission in Oslo by Poland's Provisional Government of National Unity, envoy Mieczysław Rogalski (April 1946), Rolf Andvord's mission in Poland (August-September 1945), coal contract and establishing diplomatic relations with Poland, envoy Alfred Danielsen in Warsaw (November 1945).

\section{Summary}

The article depicts the process of establishing diplomatic relations between Poland and Norway after the end of the Second World War, which started in August 1945 and ended in April 1946. The article is composed of two basic parts. The first part describes the efforts of the Polish Government in Exile to maintain the Polish diplomatic mission. Next it presents the activities of Colonel Tadeusz Tokarz, military attaché of the Mission of the Republic of Poland, accredited to the Norwegian Government in Exile in London, concerning the varied assistance for several thousand Poles gathered in repatriation camps, mainly in Moss and Mysen. At the end of the first part the author explains how and why the Polish Mission in Oslo was taken over on April 6, 1946 by Mieczysław Rogalski, the Communist representative of the Temporary Government of National Unity in Warsaw. He describes the first diplomatic contacts with the Norwegian authorities. In the second part a special attention was paid to the presentation of the endeavours of the Norwegian

* dr hab. Emilia Denkiewicz-Szczepaniak prof. UMK, Uniwersytet Gdański, Instytut Skandynawistyki, e.denkiewicz@interia.pl. 
Government aimed at establishing - as soon as possible - their own diplomatic mission in Warsaw. The description concentrates on the central role played by Rolf Otto Andvord, the Norwegian Ambassador in Moscow, during his two-month mission in Poland concerning commercial and diplomatic matters. The mission took place in August and September 1945. Andvord was charged with two tasks: to sign a contract with the Polish authorities for a fast delivery of coal to Norway and to establish fast and good diplomatic relations with Poland. It has been emphasised that Andvord was provided with a threeroomed accommodation for the Norwegian Mission at the 'Polonia' Hotel. At the end of the article there is a short life history of Envoy Alfred Danielsen, who arrived in Warsaw on November 12, 1945, and a description of his first diplomatic activities and contacts with the Polish authorities.

\section{Establishing Diplomatic Relations on the Part of the Polish Authorities}

Establishing diplomatic relations between the Provisional Government of National Unity (Tymczasowy Rząd Jedności Narodowej, TRJN) and the Norwegian Government in 1945 was much more difficult as in the case of Sweden or Denmark. After Hitler invaded Norway Władysław Neuman, a Polish envoy in Oslo, together with the Norwegian Government, went to Great Britain and there he continued fulfilling his duties till October $31^{\text {st }}$, 1942. ${ }^{1}$ Władysław GüntherSchwarzburg replaced Władysław Neuman and held his post formally till July $5^{\text {th }}$, 1945. ${ }^{2}$ During the war the Polish fought together with the Norwegians at Narvik, and the Polish Government was one of the three coalition partners of Norway. Yet, when the war ended the Norwegian Government did not grant consent for the representation of the Polish Government in exile together with the Norwegian Government to come back to Oslo. The talks concerning that question held by Günther-Schwarzburg first with Haakon VII, the King of Norway, on May $12^{\text {th }}$, and later - on May $15^{\text {th }}$ - with Trygve Lie, Minister of Foreign Affairs, did not produce the desired result, in spite of the courteous conduct of the Norwegian partners. The Norwegian Government decided to stall for time, giving false hopes instead of a positive solution. The Norwegians knew that the position of

\footnotetext{
Władysław Neuman (1893-1945), a Polish diplomat, chargé d'affaires in Tallinn (1921-1922), envoy in Oslo (1.09.1931-31.10.1942); the Norwegian King Haakon VII trusted and liked him, from October 31st, 1942 to January 24th, 1945 an envoy of Poland in Mexico; cf:: Historia dyplomacji polskiej, vol. IV (1918-1939), ed. P. Łossowski (Warsaw: PWN, 1995), 631, 638; also: http://www.ipsb.nina. gov.pl/a/biografia/wladyslaw-neuman, access 4.03.2017.

2 Cf.: M. Gawinecka-Woźniak, Stosunki rzadu polskiego z rządem norweskim na emigracji w Londynie w latach 1940-1945 (Toruń: Druk-tor, 2008), 81-88.
} 
the Polish Government in London was unstable and they waited for the situation in Europe to normalise and for the Governments of Great Britain and the USA to adopt an attitude towards the Polish question. ${ }^{3}$

\subsection{A Struggle to Keep the Diplomatic Mission in Oslo by the Polish Gov- ernment in Exile - Wiesław Patek's Efforts (May $25^{\text {th }}-$ August $15^{\text {th }}, 1945$ )}

The Polish Government in Exile in London decided - despite everything - to take action to keep on the Mission in Oslo and not to let in representatives of the Communist Government from Warsaw. For that reason it sent to Oslo Wiesław Patek, the Secretary of the Polish Diplomatic Mission in Stockholm ${ }^{4}$. Patek arrived in Stockholm as early as on May $25^{\text {th }}$ and - according to the instructions of Henryk Sokolnicki, the Plenipotentiary Minister in Stockholm - he was to reopen the Mission and start functioning, as far as possible, as chargé d'affaires; and should it fail he was supposed to remain there as an observer. In his talks with the Norwegians Patek emphasised the need to organise help for about 25,000 Poles staying in the Norwegian territory (15,000 from the Wehrmacht; 7,500 from OT and 1,500 POWs). As early as on May $26^{\text {th }}$ he got in touch with the Branch Office of the Norwegian Government in order to obtain information about the arrival of a new Polish Mission from London, and he was replied that such a mission was not included in the list of foreign diplomatic posts that were to come together with the Norwegian Government ${ }^{5}$.

Since his arrival in Oslo Patek had been very active 'organising' the work of the Polish mission. His activity is worth analysing as it shows how difficult the Polish political situation was just after the war. Patek, as a representative of the Polish Government in Exile, first of all strove to establish contacts with the Norwegian authorities, which was hardly possible before the beginning of June, when Johan Nygaardsvold, Prime Minister, and the whole Norwegian Government returned from exile; between 14 and 31 of May only the Branch Office, already

Ibidem, 142-143.

4 Wiesław Patek, born on December 18th, 1909, in Warsaw, died on April 11th, 1994, in Stockholm, columnist; in the interwar period bound with 'Bunt Młodych' and 'Polityka'; since 1933 in the diplomatic service in Moscow, Paris, Strasbourg, Oslo, Stockholm; May 5 - August 15, 1945 chargé d'affaires in Oslo; 1946-1948 in a Swedish shipping company; a university lecturer (historian, expert on Eastern Europe); 1951-1971 columnist of 'Svenska Dagbladet': https://encyklopedia.pwn.pl/haslo/ Patek-Wieslaw;3954976.html, access 4.03.2018.

5 Gawinecka-Woźniak, Stosunki, 143. 
mentioned, functioned in Norway, which was composed of five ministers headed by Prince Olav, and the expeditionary corps under the command of General Andrew Thorne. ${ }^{6}$

The very first thing Patek dealt with in the Norwegian Ministry of Foreign Affairs (Utenriksdepartementet, UD) was an attempt to get back the seat a villa at 33, Josefinesgate - of the Polish Mission in Oslo. Patek was staying in the centre of Oslo at the Grand Hotel, which had become a seat of the Polish Mission for an undefined time. Whereas in the former seat of the Polish Mission one of the rooms had been occupied during the war by the Union of Brewers (Bryggeriforeningen), and the other rooms were cluttered with packed furniture and other objects of the Polish Mission. When Patek had learnt about it he tried to recover that furniture, getting in contact with the Norwegian UD and Astrid Hesselberg, the owner of the building where the Mission had been housed. After many such contacts Ms Hesselberg informed Patek that most of the furniture had been stolen by the Germans, and the rest had been left as security for the unpaid rent. Patek's efforts to recover the furniture came to nothing in the end. Nevertheless, Stanisław Szydłowski, an ancient secretary of the Mission, managed to recover part of his private furniture he had left there in August 1939, when he arrived in Oslo from London in February 1946 and talked about it with George Collin, a protocol secretary in UD? ${ }^{?}$

Another question - much more important - was to recognise Patek as chargé d'affaires by the Norwegian Government. For that reason, on June $26^{\text {th }}$ Patek paid a visit to Trygve Lie, Minister of Foreign Affairs, who informed him that the recognition had to be put off because of the existing political situation. After that visit, still on the same day, Patek paid a visit to Rasmus Skylstad, a secretary of UD, expressing understanding for the decision of the Norwegians, made under pressure, to establish contact with the new Polish Government. At the same time he underlined that the only thing he wanted was to be useful in solving the problem of the large number of the Polish forced labourers and POWs and the Poles

6 E. Denkiewicz-Szczepaniak, Norwegia na drodze dylematów i przemian 1945-1949 (Toruń: TNT 1992), 26-35.

7 Riksarkivet Oslo (henceforth: RA), Utenriksdepartementet (henceforth: UD) 1940-1949, Eske (henceforth: E.); 10165, note of G. Collin dated 12.02.1946. In the note, in addition to a description of the question of the furniture in the Polish mission, there is a mention of the fact that in August 1945 the Polish charge d'affaires in Stockholm (J. Pański - E. D.-Sz.) sent a note to the Norwegian UD asking for help in securing and sealing the Polish movables in Norway. The note was sent to the Norwegian Ministry of Justice, which in a letter dated 29.08.1945 replied that the movables in question were mostly office equipment that had been occupied by the Germans. 
forcibly conscripted into the Wehrmacht who found themselves in the Norwegian territory. According to him, he might turn out to be really useful, as the Polish liaison officers in the Allied Command had no direct contacts with the Norwegian civil authorities. Skylstad took a positive stance on that question, and consented to Patek's further activity concerning the Polish in the Norwegian territory, but he added that 'he must be prepared for the relations to change, when the new Polish Government had to be recognised'. ${ }^{8}$

On July $10^{\text {th }}$ Patek again arrived at UD so as to lodge - on the behalf of the Polish Government in Exile - a formal protest against the recognition of the Provisional Government of National Unity by the Norwegian Government on July 6. At the same time he tried to return to the question of his status, again expressing his wish to continue his activities for the Polish DPs (displaced persons). As a reply he heard from Per Prebensen, an adviser to the Minister of Foreign Affairs of Norway, that 'he had been considered persona non grata and obtained eight days to leave the country'. ${ }^{9}$ Patek's argument that there was a universal rule that Polish diplomats enjoyed a right to remain in the country where they had been staying, was rejected. According to the documents that have been analysed the Norwegians wanted to help the Polish suggesting the same solution that was applied to the Polish DPs; they had had a choice of where to go; inter alia, they might choose Great Britain and obtain British citizenship. ${ }^{10}$ Yet, the situation changed dramatically when a counsellor of the USSR Embassy in Oslo (of unknown name) paid a visit to the above mentioned protocol secretary Collin on July $18^{\text {th }}$ asking about Patek, who still stayed at the Grand Hotel and was quite active. Collin replied,

I told him that Patek had come to Norway and the Norwegian Government did not know anything about it, and that UD - after the Norwegian Government came back to the country - informed Patek that he could not be recognised as the Polish chargé d'affaires, but the authorities agreed that he might deal with the Polish POWs and deportees in the territory of Norway. I explained to him that after the Norwegian Government had recognised the new Government in Warsaw UD informed $\mathrm{Mr}$ Patek that under the circumstances he could not deal with the Polish DPs any longer and should leave Norway as soon as possible.

\footnotetext{
8 Ibidem, note of R.B. Skylstad dated 26.06.1945: Den polske representasjon i Oslo, p. 1-2.

$9 \quad$ Ibidem, note of P. Prebensen dated 11.08.1945: W. Pateks stilling, p. 1.

10 Ibidem, Handwritten annotation to the above mentioned note dated 16.07.1945, signature illegible.
} 
Then, according to what Collin writes, the Soviet representative remarked, 'since Mr Patek is still staying at the Grand Hotel, it is impossible for the Russian Embassy not to notice that he is still visible in his activities and still receives many applicants'. Collin apologised and said that Patek had ignored the official recommendation to put an end to his activities. In the end the secretary said, 'we shall deal with that'. ${ }^{11}$

As a result, as late as on August 27, in his note dated July 11, P. Prebensen, a counsellor to the Minister of Foreign Affairs, made a handwritten annotation, 'After many attempts to persuade him, Patek finally left the country - as already mentioned on September 15 - for Stockholm.' ${ }^{2}$

Undoubtedly, the intervention of the Soviet Embassy in Oslo was a key factor in the decision of removing Patek from Oslo. It seems justified to claim that if it had not been for that intervention, Patek would have been continuing his work for the Polish DPs in Norway.

\subsection{The Activity of Colonel Tadeusz Tokarz, a Military Attaché of the Mission of the Polish Republic in London, concerning the Polish Camps in Moss and Mysen}

Just after the Second World War a representative of the Polish who had been fighting alongside the British, an officer of the General Staff of Władysław Sikorski, came from Great Britain to Oslo; during the war he had supported and organised the military cooperation between the Polish and the Norwegians. It was colonel Tadeusz Tokarz. Since March 15 th 1942 he had been occupying the post of military attaché in the Mission of the Polish Republic, accredited to the Norwegian Government in exile in London. ${ }^{13} \mathrm{He}$ arrived in Oslo on May $8^{\text {th }}$ together with the Norwegian military corps and the High Command of Defence (Forsvarets Overkommando), where he was accommodated at the Grand Hotel. His presence in Oslo was recorded in documents issued on a trivial occasion when food ration

11 Ibidem, note of G. Collin dated 18.07.1945, Den polske legasjonssekretaer Patek, p. 1-2, cf.: K. Tarka, Emigracyjna dyplomacja. Polityka zagraniczna rzadu RP na uchodźstwie 1945-1990 (Warsaw 2003), 23-24.

12 RA, UD 1940-1949, note of P. Prebensen dated 11.07.1945, W. Pateks stilling, p. 1.

13 Ibidem, E.10345, 20.20 Fremmede statsborgeres St. Olavs Orden, 91. Polen, bd. I, letter from Det kgl. Forsvarsdepartamentet to Utenriksdepartamentet, 21 Sept. 1946, which informs that the Commander-in-Chief of the Norwegian ground forces proposes to decorate with the Cross of Freedom of the King Haakon VII two Polish officers: general Stanisław Sosabowski and colonel Tadeusz Tokarz. 
coupons were given out. According to Otto von Hanno, a Norwegian lieutenant-colonel, Tokarz was given meals in the officers' canteen at the Bristol Hotel. In November 1945, when the officers' canteen at the Bristol Hotel was closed down, colonel Tokarz had to be provided with ration coupons for civilians. That is why with the full knowledge of the Norwegian High Command of Ground Forces (Haerens Overkommando) lieutenant-colonel Otto von Hanno turned first to the Ministry of Supplies and next to the Secretariat of UD. There, as he writes in his note, he heard that Tokarz might be given ration coupons only waiting for them in a queue as a civilian private person, and not as a diplomat. Further he adds,

I fear to think that the Soviet Union might use repressive measures against Norway if we continued to treat the representatives of the Government in Exile friendly, which we have been doing for the last five years. I suspect that it would be advantageous if the way of thinking and behaving of those young diplomats could bring about more harmony with their innocent attitude..$^{14}$

The decision was made by the Head of the diplomatic protocol of UD, Cerge Collin, on November 12th, who confirmed that he had talked to major Hanno during his visit at UD. The worst in the whole story - according to what Collin writes - was that the major - in spite of expressing understanding for the developing of the situation in that way - went to Rasjoneringskontor in Oslo and confirmed the right of Tokarz to be given coupons as a diplomat, citing as the authority his talks in UD. In that way Tokarz was given coupons, but the clerk at the office telephoned to UD asking for confirmation whether Tokarz was entitled to coupons as a diplomat and it was just that telephone call that caused all the commotion. ${ }^{15}$

A conclusion arises that the Norwegian major tried to save the situation of Tokarz, taking the risk of his own insubordination to the authorities. He behaved as a normal man, who wanted to help another in need. Undoubtedly, he seemed not to fully understand the sudden change in behaviour of his Government towards one of the three allies, the Polish ally, with whom - like with the British and the French - Norway had been cooperating throughout the war. In addition, colonel Tokarz was the most important person, who had helped to organise schools in

14 Ibidem, letter from major Otto v. Hanno dated 7.11.1945 to Det Kongelige Norske Utenriksdepartement, entitled Yngre diplomaters opptreden, p. 1-2.

15 Ibidem, note of Klavenes dated 12.11.1945, Rasjoneringskort til ,,den polske militaerattache”, and an attached whole-page handwritten annotation of the head of Protocol G. Collin with the same date. 
Mysen and Moss for those Poles who did not want to return to Poland. When in April 1946 Mieczysław Rogalski, an envoy of TRJN, came from Warsaw to Oslo, Tokarz together with the liaison officers were put under surveillance on the part of the Polish Mission. Tokarz was the central figure among the Polish Londoners. He came to Oslo to support repatriation, and at the same time he was seeking ways to gather the Poles who decided to remain in Norway in one organisation, the Polish Union with its headquarters at 53b, Munkendammsveien. The seat of the Polish Red Cross, a branch of the Norwegian Red Cross, was located at the same address. All the correspondence concerning the Polish was sent to that address, and it was so still after Rogalski had come to Oslo. In the same street, at number 36, there was a Norwegian company (Maskinutstyr), which produced spare parts for machines; Tokarz was employed there and in that way he could remain in Norway legally. It was very important as Tokarz often left for London, organising help for the Polish schools in Mysen and Moss in the form of textbooks, paper, exercise books, as well as financial means. His last departure to London took place in June 1946. On August $31^{\text {st }}, 1946$ envoy Rogalski paid a visit to UD complaining about Tokarz's activity among the Polish addressed against the Warsaw Government. He also added that Tokarz had come back a few days before and now he intended to set up a Union of Poles under the direction of captain Roman Budka, and had been charged with the task of handing over the Golden Cross of Merits, brought from London, to major Harrisson, the military attaché of the USA Embassy in Oslo and an opponent of the Polish regime. Rogalski was promised that the whole thing would be investigated through the diplomatic channels..$^{16}$ The results of that investigation were to be found in the Norwegian documents in the form of seven letters and notes made by UD and the Main Passport Office (Sentralpasskontoret, SK); the documents depict who gave Tokarz a visa to stay and later return to Norway and what was done to expel him from Norway. According to the documents Tokarz stayed in Norway till June 1946, and then, before he went to London he had asked Knut Nicolai Stilloff, the head of SK, to give him a return visa, which Stilloff refused to give his consent to, and he also refused to give him a work permit in Norway. Suspicion arose that the return visa was issued by the Norwegian Embassy in London. ${ }^{17}$ UD secretary Collin asked colonel H. Haneborg Hansen

16 RA, Sos. dep. FFD, Sentralarkiv, E-saksarkiv, E.0087, mappe 9.1121 Polakker, bd. XIII, Notat fra UD av 31 August 1946; cf.: AMSZ, Z.6, T.1096, W.76, Political report of the Polish envoy in Oslo M. Rogalski to Minister J. Olszewski, Oslo 30.08.1946, k. 24.

17 Ibidem, Erik Dons, Notat av 2 Sept. 1946. 
from the military staff to clarify the situation via the Norwegian military intelligence. The latter writes that major Karl Evang from the command of the military intelligence service informed him that,

Tokarz is «a persona non grata» here in Norway, and his activity may lead to nasty things. He should leave Norway. Tokarz has links to anti-Russian circles and hence to Sweden where people flee to. In addition, he has huge financial means, the origin of which is difficult to define. ${ }^{18}$

Quite soon it turned out that neither the Embassy of Norway in London nor the Consulate in Leigh issued the return visa. Nevertheless, the investigation was not fruitless; it proved that Tokarz had had the so-called British re-entry permit valid till September $25^{\text {th }}, 1946$. In virtue of that permit he was given a visa by the Norwegian Passport Control Office in London. Having that document Tokarz was allowed to move about Denmark and Sweden, too. In September he was in Denmark; that is why it was decided not to allow him to enter Norway and send him from the Oslo airport to England avoiding thus the situation of forcible expulsion from the country..$^{19}$ On November $4^{\text {th }}, 1946$, as Mieczysław Rogalski, an envoy of the Republic of Poland, writes, P. Prebensen, the secretary general of the Norwegian UD, informed him officially that colonel Tokarz had left for London, and 'some authorities have obtained instructions so that he would never be granted an entry visa again'. ${ }^{20}$ Rogalski, in his inquiries concerning organising the pro-London Polish community, stated that he was an official representative of reactionary circles of London. He added that Tokarz was on the list of the Organisational Committee of Education in Germany, situated in London, and that he was the person the Polish repatriation camps in Norway could communicate with in all questions and take instructions from. Rogalski regarded Tokarz's activity as harmful, and herewith he substantiated his aide-mémoire addressed to the Norwegian UD, with which P. Prebensen, the above mention secretary general of UD, had to agree and take appropriate action. ${ }^{21}$ Rogalski added that there was still another important question, which was a kind of pressure both on the Polish Mission in Oslo and the Norwegian authorities. It was the information that

\footnotetext{
18 Ibidem, notat av H. Haneborg Hansen, 20 Sept. 1946.

19 Ibidem, notat fra den norske ambassaden i London av 20 Sept. 1946; notat av Erik Dons, 26.09.1946.

20 AMSZ, Z.6, W.76, T.1096, Political report of Polish envoy in Oslo M. Rogalski dated 9.11.1946 to Minister J. Olszewski, Political Dep. of the MFA, k. 31.

${ }^{21}$ Ibidem, k. 30.
} 
Rogalski had been visited by colonel Petrenko, the military attaché of the Soviet Embassy, who was to say that the Polish from the camp in Mysen, whom Tokarz had been helping, might have been trained as parachutists who were to join the Polish bands fighting against the new authorities in Poland. ${ }^{22}$

Like in the case of Patek, the fate of colonel Tadeusz Tokarz, who got engaged in helping the Polish remaining in Norway, was decided because for purely political reasons, and a special role was played by the pressure of the Soviet Embassy in Oslo. Hence the excessive activity of Rogalski to eliminate 'all the London elements' from the Norwegian territory as soon as possible.

\subsection{Bjarne Holter-Sørensen, a Pro Tempore Honorary Consul General}

Norway waited longer than the other Scandinavian countries for a diplomatic envoy from Warsaw. An attempt made by the Polish Government in Exile to place its own envoy in Oslo failed, still taking care of the huge number of the Polish was a problem to solve. The Norwegians themselves demanded a Polish envoy be sent as soon as possible, which was the matter of their prestige. They were not interested in appointing a common envoy for Sweden and Norway with the seat in Stockholm on account of their recent forced union with Sweden. Rolf Andvord, the Norwegian ambassador in Moscow, expressed it during his visit to Warsaw at the beginning of August 1945; he came to Poland to prepare a place for the Norwegian mission in Warsaw and to establish the first diplomatic and commercial contacts with Poland (these questions will be dealt with later). On August 6, during his visit to the Polish Ministry of Foreign Affairs (MFA) he complained that since his departure from Moscow he had not received any reply to his note of recognising TRJN by Norway. He also asked that there be an independent envoy in Oslo and that such an envoy be sent as soon as possible, because 'the Norwegian Government attaches a lot of weight to it.'. ${ }^{23}$

The Polish authorities were informed about the situation in Norway by a person, whose name appeared while the Polish Repatriation Mission was being organised. It was Jerzy Halwic, a former worked of OT; in 1942 he had come to the region of Alta in northern Norway with Bodmann $u$. Hildebrandt, a German company from Łódź where he was employed as an accountant. After the war, like

\footnotetext{
22 Ibidem, Political report of Rogalski dated 30.08.1946, k. 24.

23 AMSZ, Z.6, W.76, T.1091, pro domo note dated 6.08.1945, k. 1.
} 
many of over the 7,500 Polish forced workers of the Todt Organisation (German: Organisation Todt, OT) he waited to be evacuated in one of the dozen or so camps for civilians. At that time he was recruited by Jerzy Pański, chargé d'affaires of TRJN in Stockholm, into cooperation with the Communist Government in Poland. ${ }^{24}$

J. Pański, a Polpress correspondent and an organiser of the Union of Polish Patriots in Sweden during the war, was nominated for his post in three Scandinavian countries, Sweden, Denmark and Norway, and held it from July to September $3^{\text {rd }}, 1945$. A denouncing letter handwritten by Halwic in August 1945, i.e. when he still was in Norway, proves that he had a good knowledge of the situation in Norway. He depicts the situation in that country, mentioning the people related to the London Government, including the Polish liaison officers who looked after POWs and civilians. ${ }^{25}$ Halwic's report must have been a stimulus for the authorities in Warsaw to start dealing with the huge number of the Polish in Norway; that number was three times bigger than that in Sweden, and they should be evacuated to Poland as soon as possible. It might be easier as at the beginning of September to the Polish Mission in Stockholm TRJN sent Adam Ostrowski, who soon got support in the territories of Denmark and Finland, and he writes to the Consular Department of the Polish MFA:

...in view of the arrival of chargé d'affaires, dr Szymański, in Denmark, and expecting the post in Finland to be soon taken up, I could restrict myself to Norway. According to the order of Ministry I turned to Mr Germanowič, the envoy of Yugoslavia for the Scandinavian countries in Norway, who agreed that the honorary consul general of Yugoslavia in Norway, Mr Bjarne Holter-Sørensen, domiciled in Oslo, (Toldbodgatan 11, telephone number 23 700) could deal with urgent matters of Polish citizens until the Polish mission was established.

24 In one of his reports to the Director of the Political Department of the Ministry of Foreign Affairs Pański writes about his visit in Oslo at the invitation of the Norwegian Government concerning the Poles in Norway; he underlines that he was received with full honours by the Minister of Interior S. Oftedal and the commander of Russian troops general Ratow; he says that the Norwegian Government held a conference of delegates from Polish camps, where the question of repatriation of the Polish was discussed. He mentions that a vote of no confidence was expressed concerning the liaison officers of the London Government and that he was asked to send liaison officers from Poland. In the end, which was characteristic, he adds that five liaison officers should be sent to general Thorne or should be nominated from among the Polish officers and soldiers in Norway. The whole report in: AMSZ, Z.6, W.78, T.1165 Political notes [Jerzy Pański, Adam Ostrowski], report no. 5 to the Director of the Department J. Olszewski, k. 20.

25 Ibidem, Z.6, W.76, T.1092, Jerzy Halwic, Sprawozdanie z działalności osób szkodliwych dla Państwa Polskiego na terenie Norwegji, p. 6. 
He informed the Ministry of Foreign Affairs that just to settle that matter Tadeusz Tabaczyński, head of the Consular Department, went to Norway and he talked to both Sørensen and Collin in the Norwegian UD. As a result Sørensen agreed to act as a consul, and in more important matters, especially related to evacuation, he was to turn to the Consular Department of the Polish Mission in Stockholm. ${ }^{26}$ All these facts are confirmed in Norwegian documents; e.g. in his letter dated November $18^{\text {th }}$, Collin writes that Holter-Sørensen telephoned him first (November $17^{\text {th }}$ ) and the following day he asked again on the telephone whether he might pay a short visit together with the secretary of the Polish Mission in Stockholm (no names were mentioned). In spite of the fact that it was Sunday both gentlemen were received by Collin. The Pole explained that the Polish authorities were not able - on account of the problems with the post and telegraph - to send a letter from Warsaw; that is why it was done by the Mission in Stockholm. He added that the matter was urgent taking into consideration a big number of problems, which the Mission in Stockholm could not solve, and hence the post might be temporarily taken up by Sørensen until the Polish envoy came to Oslo. Collin consented to such a solution, and he added that also the Polish consuls of the pre-war time might continue to perform their function automatically without the need to issue new documents (eksekvatur). ${ }^{27}$ Sørensen's activity has not been confirmed by any documents. His work must have been restricted to the most urgent consular matters. In practice, the Polish awaiting evacuation or a departure to another country were served by Norwegian institutions that cooperated with the Allies.

\subsection{Taking up the post by Mieczyslaw Rogalski, a TRJN Envoy}

As late as in mid-February 1946 the decisions were made in the Polish MFA concerning the candidature for the post of envoy in Norway. On February 15 M. Rogalski was given a letter of accreditation to Haakon VII, king of Norway, signed by Bolesław Bierut, and on February $19^{\text {th }}$ Bierut, the President of KRN, informs Rogalski, at that time Director of the Consular Department of MFA, that he had been appointed extraordinary envoy and minister plenipotentiary to the Government of the Kingdom of Norway in Oslo. We learn from the Norwegian

26 Ibidem, Z.6, W-76, T -1090, Letter of A. Ostrowski dated 20.11.1945, to MFA, Consular Department in Warsaw, k. 1.

27 RA, UD 1940-1949, box 10165, 14.21/91 Polens sendemann i Norge, Note of Collin dated 18.11.1945 entitled Polens representasjon i Oslo, p. 1-2. 
press that envoy Rogalski together with his wife arrived in Oslo on Saturday April 6 on board a plane from Stockholm, where he had been staying since April 3.

Mieczysław Rogalski was born in Warsaw in 1889. He finished his secondary school in the capital, and started his university studies first at the Faculty of Law in Liège, Belgium and later at the Faculty of Philosophy of the Jagiellonian University. He also graduated from the Diplomatic-Consular Faculty of the Political Science School in Warsaw. From 1916 he was a teacher in the newly created Lublin University. In the years 1919-1928 he was employed at MFA, and in the years 1928-1930 he was secretary of the Polish Mission in Bucharest, Romania; afterwards he returned to the Consular Department, where he worked till 1932 in Legal-Revindication Section. From 1932 to 1939 he was consul in Eastern Prussia, first for a year in Olsztyn (German: Allenstein) as a vice-consul of the first class, and in the years 1933-1935 as Polish Consul in Kwidzyń (German: Marienwerder), from 1935 to the outbreak of the war as Consul General in Ełk (German: Lyck). In September 1939 he managed to force his way through to Poland and hide in Lublin. There for six years he was a simple labourer, a painter. From July to August 1944 he was involved in the activity on behalf of the Lublin Government, organising the system of education. Since August $24^{\text {th }}, 1944$ he was employed in the Ministry of Foreign Affairs and cooperated with Prime Minister Osóbka-Morawski and Minister Jakub Berman. In September he represented the Government in the matters concerning evacuation, and in December 1944 he became an MP of KRN on behalf of the Democratic Party, where he was a member of the presidium. On January $1^{\text {st }}, 1945$ he was appointed director of the Consular Department of MFA. He was actively engaged in the political work on behalf of PKWN; he was a member of several societies, such as the Polish-Soviet Friendship Society or the Polish-French Friendship Society. It is worth mentioning that in his youth until 1918 he had been active in the Polish Socialist Party - Left (PPS-Lewica) and since 1918 for ten years in the Polish Peasant Party - Liberation (PSL-Wyzwolenie). He was not affiliated to any political party from 1928 to August 1944, when he got engaged in the underground activity of the Democratic Party as commander of the Lublin Region of OWO (Obóz Wyzwolenia Ojczyzny, Camp of Liberation of the Homeland). Married to Ludwika Klaudia, née Potocka on December $21^{\text {st }}, 1916$. From his first marriage he had two children, who perished in Warsaw during the Warsaw Uprising in $1944 .{ }^{28}$

28 AMSZ, Purchase 24.97, W.17, Personal card of M. Rogalski dated 17.01.1945 and his cv, k. 3-7. 
Mieczysław Rogalski was an experienced diplomat and a clerk of the MFA administration of many years' standing. He spoke the language of diplomacy French - fluently, and in addition he knew German, Russian and Romanian. So he was well prepared to work in international diplomacy, although it was the first time he held the post of envoy. After arriving in Oslo on April, 1946, as early as April 10 he paid a visit to the Norwegian Ministry of Foreign Affairs, where he talked to Minister Halvard Lange and Per Prebensen, the counsellor and an informal deputy of Lange, and handed over the copy of his accreditation letter to the Minister. The original was submitted to King Haakon VII after Easter on April 27 $7^{\text {th }}$. He also paid a visit to the diplomatic corps in Oslo, where he met his ancient friends, inter alia the secretary of the Polish Mission in Bucharest or a friend from his stay in Belgium. He was received by the dean of the diplomatic corps, Kuzniecow, ambassador of the USSR. In a letter he informed UD that he was planning a visit to Iceland on June $10^{\text {th }}$, like many other envoys who were representatives both for Norway and Iceland. Then he would be able to submit his accreditation letter and participate in the celebrations that took place on June $17^{\text {th }}$ to memorise the second anniversary of proclaiming Iceland an independent country. At the same time, on account of the fact that the Icelandic envoy for Norway had his residence in London, he would establish relations with the Icelandic envoy for Sweden and hand over the copy of his accreditation letter to him with a request to send it, according to the customs existing in Oslo, to his government in Reykjavik. ${ }^{29}$

In a separate letter to Minister Józef Olszewski, head of the political department of MFA of the same day (April 10 $0^{\text {th }}$ ) he depicted the situation he had encountered in Oslo. He underlined considerable influence of the Polish Government in Exile on the Polish DPs who were in the repatriation camps in Norway, and as he put it 'it will be necessary to crush it somehow'. He added that the cause of the campaign against Communist Poland in the Norwegian press had been - inter alia - the fact that there had been no Polish representative in Norway for too long. He also mentioned the poor housing standards of the Mission, which was located in two rooms at the Grand Hotel in Oslo. Together with his wife he occupied the bigger room with an alcove, and the other room served as the office of the Mission, where clients were received. Rogalski also complained about the

${ }^{29}$ Ibidem, Z.6, W.76, T.1094 - Taking over the mission by Mieczysław Rogalski, handwritten letter of Rogalski to minister J. Olszewski dated 10.04.1946, k. 1-2. 
scarcity of means to pay for accommodation; it was a cost of 60 kroner (basic price) daily; that is why the personnel of the Mission were located in cheaper third-rate boarding houses or pensions. The envoy also complained about the too modest - compared to other missions - number of staff, smaller than he had fixed in the Personnel Office before leaving for Norway. Instead of six persons there were only two: the second secretary Andrzej Zalewski and the head of the office K. Święcicki. At the end of the letter Rogalski emphasised the need to increase the budget of the Mission and the need to make the Personnel Office increase the number of the staff, first of all to employ commercial attaché $e^{30}$. And shortly afterwards, at the beginning of June 1946 the Mission managed to rent a two-storey villa at Olav Kyrres Plass 1, where the Mission was moved and started work on June $12^{\text {th }}, 1946 .^{31}$ The Polish Mission has been located there until now.

\section{Establishing Diplomatic Relations on the Part of the Norwegian Authorities}

Norway fairly early recognised the Provisional Government of National Unity (Tymczasowy Rzad Jedności Narodowej, TRJN) formed on June $28^{\text {th }}$, 1945. It took place on July $6^{\text {th }}$, just one day after it had been done by the USA and Great Britain. ${ }^{32}$

The Norwegians, like the Swedish and the Danish, had problems with fuels, coal and coke, to heat houses, and for the needs of industry. Additionally, they were deprived of supplies from Great Britain and Germany, so they soon diverted their attention to Poland, rich in coal. ${ }^{33}$ It was one of the main reasons for which those countries recognised TRJN so soon, although in the case of Norway it was not the only reason. It is worth reminding that as a result of the so called continuation war (1941-1944) between Finland and the USSR the northern patch of Finland, Petsamo, was annexed to the territory of the Soviet Union (the present

${ }^{30}$ Ibidem, Z.6, W.76, T.1096, handwritten letter by Rogalski to minister Olszewski dated 10.04.1946, p. $1-2$.

31 Ibidem, Z.6, W.76. T.1095, Report of Przesmycki dated 15.06.1946 of the official trip to Oslo and Copenhagen, k. 2.

32 W. Materski, Dyplomacja Polski "lubelskiej" lipiec 1944 - marzec 1947 (Warsaw 2007), 281.

33 Cf.: E. Denkiewicz-Szczepaniak, "Polsko-norweskie kontakty handlowe w latach 1945-1949", Dzieje Najnowsze XXXVIII (2006) 4: 109-122. 
name: Pechenga; Russian: Пече́нга). ${ }^{34}$ In that way Norway began to have a common land border with the Soviet Union, $196 \mathrm{~km}$ long, which at the end of the WW2 changed the political situation of Norway. The pro-Western course in the policy of the Norwegian Government was stopped and replaced by the politics of balancing between the two superpowers, the USA and the USSR, referred to as 'the policy of building bridges' (1945-1949). ${ }^{35}$ Additionally, after the war the social-democratic Government of Norway with Communist participation raised at least at the beginning - some prospects of political cooperation with the states now dependent on the Soviet Union. Poland was the second most important partner (after the USSR), in addition, strategically situated and rich in coal and coke. That is why having in Warsaw their own diplomatic mission as soon as possible was for the Norwegians very important.

\subsection{Diplomatic and Commercial Mission of Rolf Andvord, Ambassador of the Kingdom of Norway in Moscow}

Sending a Norwegian envoy to Poland and placing him in Warsaw was not an easy task, mainly because of problems with transport, especially a lack of direct connection, also the telephonic and telegraphic ones. All the correspondence of the Norwegian diplomats was directed via the Norwegian Mission in Stockholm. The motive force that urged Norway to establish contacts with Poland was the deficiency of coal. The former supplier, Great Britain, as the Norwegian ambassador in Moscow, Rolf Andvord writes: ${ }^{36}$

...was no longer able to supply us with that merchandise, and Poland, where coal seams in the south were sufficiently extensive, and not destroyed, was actually the only country in Europe where coal might be extracted. ${ }^{37}$

34 Cf.: O. Jussila, S. Hentila, J. Nevakivi, Historia polityczna Finlandii 1809-1999 (Cracow 2001), 223-237.

35 Cf.: E. Denkiewicz-Szczepaniak, Norwegia na drodze dylematów i przemian 1945-1949 (Torun 1992), 63-115.

36 Rolf Otto Andvord (1890-1976), father, physician, studied law in Oslo in the years 1910-1915, next he assumed the post of secretary in UD, after a few years as chargé d'affaires in Copenhagen, in 1921 nominated secretary, and then envoy in the Mission in Paris, afterwards he spent a short time as counsellor in the mission in London, in 1935 he was nominated envoy in Argentine with accreditation to many South-American states; Norwegian ambassador to Moscow (1941-1946), Paris (1948-1958) and Madrid (1958-1961), where he ended his diplomatic career; cf.: https://nbl.snl.no/ Rolf_Andvord, access 8.03.2018.

37 R. Andvord, Med hånden på hjertet (Oslo 1964), 278. 
And the Norwegian Government charged Andvord, who had been staying in Moscow since 1941, with a quick diplomatic action, because sending a diplomatic representative immediately to Poland was not easy on account of the reasons mentioned above, and it was a known fact that the Swedish had signed a preliminary contract for supplies of coal already on June 29th. As Andvord was on holiday, the first talks with representatives of TRJN were initiated in Moscow by E. Krogh-Hansen, a counsellor of the Norwegian Embassy in Moscow. The first meeting took place on July 2nd, on the day when the delegation of TRJN headed by Hilary Minc, the Minister of Industry, came to Moscow; the second - on July 17th with Zygmunt Modzelewski, Ambassador of TRJN in Moscow, who in the meantime was nominated vice-minister of foreign affairs of the Warsaw Government, and two days later together with his trade consultant, Zygmunt Wyrozembski, was to leave for Warsaw. Modzelewski promised to draft a Norwegian-Polish coal contract, based on the Swedish-Polish contract signed for five years and 500,000 tonnes of coal, and it needed to be coke and bunker coal as well. In turn Norway was to supply herring and fish oil. Modzelewski suggested that Krogh-Hansen come to Warsaw the following week to sign the contract and recommended that he take a few coal and transport experts with him. ${ }^{38}$ Luckily, on July 20th Andvord was already in Moscow and could personally see vice-minister Modzelewski to the airport. Modzelewski agreed with Andvord that he would give him all the details concerning the sorts of coal on the phone from Warsaw and at the same time he invited the Norwegian to Poland. To that end UD sent Andvord a confidential report with the basic offer concerning the quality and quantity of the merchandise from both sides (coal: 500,000 tonnes, $45 \mathrm{~mm}$ large, and at least 100,000 tonnes of coke, and approximately 50,000 tonnes of bunker coal) together with a recommendation to seek coal as large as possible; the USA and Great Britain offer only small coal (slack). In its report UD underlined that there was a need for more coke, preferably 250,000 tonnes, which would be offset by an increased number of barrels of pickle herring (instead of 100,000 - 150,000) and (medicinal) fish oil (instead of 1,000 tonnes - 1,250 tonnes). Supplies were to be delivered from both countries for five months, and the payment for the part of the value of the merchandise from Poland not offset by Norwegian goods was to be made in the pound sterling. The report also emphasised the need to make

38 RA, UD 1940-1949, Box 11592, 44.4 Handelspolitikk. Allment, 91. Polen, Bd.I 1945, Melding fra ambassaden i Moskva av 19.7.1945, J.nr 19332/45, Kull-og koks-avtale med Polen. 
a framework contract of preliminary character, after which UD would send experts to Warsaw so that they would finalise the sales and purchases.

It should be explained what the reasons for those hasty operations were. The Norwegian Mission in Moscow had received a telephone call from the Polish Embassy in Moscow with the recommendation that:

Andvord should leave immediately for Warsaw and sign the contract as the struggle for Polish coal intensifies with each day. In addition to the Danish, who have already been in Warsaw, a delegation from Finland is expected in Moscow who will go there at once, still the French and Italians have been on the way.

Under such circumstances Andvord found that the best solution would be if he signed the contracts himself instead of the Norwegian salesmen, as soon as the prices offered by the Norwegians were accepted by the Polish. ${ }^{39}$

Andvord arrived in Warsaw on July $30^{\text {th }}$ together with his adjutant, captain Just Bortenen. At the airport he was welcomed by Prince Krzysztof Radziwiłl, head of the Protocol of MFA, and then Andvord and his adjutant were accommodated at the 'Polonia' Hotel, where they put up the Norwegian flag. As he emphasised in his note of August $8^{\text {th }}$, it was the only building in the centre of Warsaw that had not been destroyed, as it was the seat of the Gestapo. The rest of the city did not exist, it was a sea of ruins. The hotel became a temporary seat of many diplomatic missions in Warsaw, the Norwegian one including, thanks to the effective activity of Andvord. It should be noted that Andvord proudly underlines the presence of Norway among other states there writing that the flag of his country 'now is hanging together with the American, British, Danish and Yugoslavian ones, whereas the population gather in front of the building are happy that the isolation of Poland is over, ${ }^{40}$ On July $31^{\text {st }}$, Andvord was received in a friendly atmosphere by Wincenty Rzymowski, the Minister of Foreign Affairs, who promised him to send a Polish representative to Oslo as soon as possible to deal with the repatriation of the Polish. Andvord was also received by Dr Stefan Jędrychowski, the Minister of Foreign Trade and Navigation, who promised him to take care of the coal contract as soon as possible.

39 Ibidem, Melding fra Ambassaden i Moskva av 27.VII.1945, no 20475/45, Kull-kjøp i Polen.

40 Ibidem, E.10601, 27.5/39B, bind VI, Confidential note of R. Andvord to the Norwegian Minister of Foreign Affairs, Warsaw 8.08.1945, p. 1-2. 
Andvord also talked to the businessmen, who had been staying in Poland since the pre-war times, inter alia Jens Ejbol, a representative of the shipping company Wilhelmsen, and Sjurd Lien, who had been running a farm of foxes near Warsaw for years; Andvord informed them about the preparations concerning the arrival of the Norwegian delegation, who were to conduct commercial negotiations with Poland. ${ }^{41}$

Andvord held the further talks with Z. Wyrozembski, Director for Trade, according to the detailed instruction of UD dated August $2^{\text {nd }}$ concerning two questions. The first question was to establish the highest and lowest prices of herring and fish oil, and to deliver 400 railway wagons to Poland to carry coal. The second question was to fix the terms of payment, which was all the more difficult as it was already known that the value of the Norwegian merchandise would be lower than the Polish one; hence the Norwegian importer of Polish coal (Norsk Brenselimport), representing the state of Norway, was to pay for herring and fish oil in the Norwegian kroner, and the rest of the Polish merchandise would be paid in the pound sterling..$^{42}$ It was supposed to simplify the settlement.

The talks with Wyrozembski were difficult and did not end with satisfactory results; that is why Andvord decided to turn to Modzelewski, the Minister of Foreign Affairs, who had invited him to Poland. Modzelewski happened to have come back from Potsdam and at the meeting with Andvord:

was surprised that the contract had not been signed yet, and said that he'd telephone Wyrozembski and he'd tell him that it was necessary to sign the contract as soon as possible. They had to sign, he repeated. Unfortunately, the Foreign Trade Minister was to fly to London to the UNRRA Conference the following day but he [Modzelewski] would try to sort everything out before his departure. ${ }^{43}$

Andvord was not altogether convinced that the contract would be finalised. That is why on the same day in the evening together with the Russian ambassador he went to the airport, where they welcomed Marshals Zhukov and Rokossovsky. He met Modzelewski there and told him that he wanted to go to Oslo soon to pass on the information and send experts. Modzelewski advised him against going to Oslo; he said that Andvord should not go without having obtained a document in

\footnotetext{
41 Ibidem.

42 Ibidem, Melding til Ambassaden i Moskva, 2.08.1945, Polsk-norsk kullavtale.

${ }^{43}$ Ibidem, p. 2.
} 
which Poland would declare the readiness to deliver coal to Norway. He added that such a declaration might be signed either by the Foreign Affairs Minister or the Trade Director, which - in short - Modzelewski managed to do. Hence on Sunday August $5^{\text {th }}$ Andvord together with captain Borthen were invited to the country estate of Trade Director Wyrozembski, where they obtained a short declaration signed by him. ${ }^{44}$ The declaration addressed to Ambassador Andvord says that the Polish Government commits itself to deliver to Norway 500,000 tonnes of hard coal, 100,000 tonnes of coke and 50,000 tonnes of bunker coal within five months. ${ }^{45}$ Captain Borthen sent that document to Trygve Lie, the Foreign Affairs Minister; to that end, on the same day (August $5^{\text {th }}$ ) Borthen went to the airport and left the document together with the description of the whole situation on board a plane flying to Stockholm. The first step to secure coal for Norway was made in that way. Now it was time to fix the details concerning sorts, prices and transport both ways, so as to finalise the contract as soon as possible. And again both gentlemen had to do their best. The Polish were not interested at all, which is reflected in the Polish archival documents, where the name of Andvord appears only once in the form of his signature on the contract (without a specification as for his post).

Andvord conducted further talks with Norwegian experts in Stockholm and the Polish ones in Warsaw until August $29^{\text {th }}$, when the contract was finally signed. Andvord described in an extensive report of August $31^{\text {st }}$ the main reasons of why the negotiations took a whole month and not five days as he had expected. At the beginning he gives five main reasons. First, he mentioned the difficult conditions in Poland, where everything was missing, experienced negotiators and experts including. Second, Norway's offer was rather modest, its value was one fourth of the value of the Polish merchandise. Third, there were enormous problems with transport to the Baltic ports. In the end he underlines the financial limitations; it was impossible to give Poland a credit to purchase herring before coal was sent to Norway or give guarantees concerning the exchange rates. In order to make quick decisions it was necessary to obtain a special authorisation of the Norwegian Government, which Andvord could not obtain on account of communication

44 Ibidem, p. 3.

45 Ibidem, Text of the announcement: Monsieur l'Ambassadeur! Par la prezent j'ai L'onneur de Vors faire savoir que le Gouvernement Polonais sera pret - sous sertains conditions stipulee dans un accord special - a delivrer Au Gouvernement Norvegien pendent les 5 moins restent de l'annee 1945 500.000 tonnes de charbon et Au moins 100.000 tonnes de coke, ainsie que 50.000 tonnes ,, bunkers”. Z. Wyrozembski. Warszava, le 5 Aout 1945. 
difficulties. He also underlines that Poland was given the credit by the Swedish (100 million kronor) and the Danish (7 million kroner). Those countries could sell Poland much more merchandise than Norway, thus maintaining a balance in commercial exchange. As for the details he mentioned that the prices of herring and fish oil were high compared to the pre-war prices, and that Norway did not have split herring at that moment, which was usually bought by the Polish. Additionally, UNRRA informed the Polish that they could count on a free gift in the form of the same merchandise Norway was offering. It complicated the negotiations, which were well under way, and the Polish suddenly announced that they did not need to buy such goods in Norway because they got them free from UNRRA. ${ }^{46}$ In spite of all those difficulties the contract was finalised and signed on August $29^{\text {th }}$. According to the annexes the quantities were kept, of coal and coke (altogether 600,000 tonnes), and additionally 50,000 tonnes of bunker coal, in which Norway had been interested from the very beginning. Till the end of 1945 Norway was to receive 150,000 tonnes. ${ }^{47}$ As Andvord underlines:

we have been assured by the Polish negotiators, both by the Industry Minister and the Director of the Polish mines, that the deliveries will be made in Polish railway wagons drawn by locomotives without the need to provide 400 Norwegian wagons and 12 locomotives to which we had committed ourselves. The Polish did not know whether they can count on their delivery till the end of the year. The remaining quantity of coal will have been sent by the end of March 1946, 150,000 tonnes monthly, and it is up to the Norwegians to decide on the proportion of coal and coke in the deliveries of the next year. ${ }^{48}$

46 Ibidem, report of R. Andvord to the Norwegian Ministry of Foreign Affairs (UD), Oslo, 31.08.1945, p. $1-2$.

47 Archives of Modern Files, Archiwum Akt Nowych (henceforth: AAN), Ministry of Treasure II, Ministerstwo Skarbu II, catalogue no 385, Contract made between TRJN of the Republic of Poland and the Royal Government of Norway to regulate merchandise exchange, Warsaw, 29.08.1945, attachment no. 3, k. 17.

48 RA, UD 1940-1949, Box 11592, 44.4 Handelspolitikk. Allment, 91. Polen, Bd.I 1945/08.05-15.09, report of R. Andvord to the Norwegian MFA (UD), Oslo 31.08.1945, p. 2. 


\subsection{Andvord's Struggle for an Additional Protocol to the Commercial Contract of August 29 ${ }^{\text {th }}, 1945$}

On August 29th after signing the preliminary contract, Andvord started to struggle for an additional protocol, which would include the detailed quantities of separate sorts of coal. The annexes only included the prices, they did not include the dates and the quantities of the deliveries in separate months, starting October 1945 till April 1st, 1946.

Andvord's activities might be divided into two parts: the first part from August $30^{\text {th }}$ to September $7^{\text {th }}$; and the second part in Poland, first in Katowice (11-13 September), next in Warsaw (13-14 September). ${ }^{49}$ Andvord takes the first steps in Oslo, where he came on August $30^{\text {th }}$ and first he went to the Central Office dealing with deliveries of fuels (Norsk Brenselimport A/S). There on September $3^{\text {rd }}$ they - Andvord and the management of Norsk Brenselimport A/S - drafted a coal contract, which was to be presented to the Central Office of Coal Industry Products in Katowice for possible corrections and approval. ${ }^{50}$ Next Andvord had a meeting with Johann George Raeder, head of Commercial Policy Department, during which a draft of the additional protocol was prepared to the contract of August 29. ${ }^{51}$ Andvord's activity during those eight days in Oslo (from September 30 to October 7) was extraordinary. He obtained a person from UD to help him, which must have been inspired by him; that person could not only assist him in the purchase of coal in Poland, but could also be a temporary diplomatic representative of Norway in Warsaw, so that Andvord might resume his duties in Moscow. Lauritz Myrebøe was chosen, a pre-war consul general in Gdańsk/Gdynia and a businessman from Bergen; already on July 25, 1945 in a letter to UD he had offered to hold that post. Myrebøe had 20-year experience in consular work in the Free City of Danzig; that is why he was the best candidate..$^{52}$

49 Cf.: E. Denkiewicz-Szczepaniak, "Misja handlowo-dyplomatyczna Rolfa Andvorda w Polsce w sierpniu i wrześniu 1945 roku”, Zapiski Historyczne LXXVII (2012) 3: 23-49.

${ }^{50}$ RA, UD 1940-1949, Box 11592, 44.4 Handelspolitikk. Allment, 91. Polen, Bd.I 1945/08.05-15.09, Contract between Norsk Brenselimport A/S as buyers and the Centrala Zbytu Produktów Przemystu Weglowego, Katowice, as sellers, the following contract made for the shipment of Polish coal and coke to Norway, p. 2; $c f:$ letter of Andvord to the minister of foreign affairs T. Lie dated 13.09.1945, p. 1.

51 Ibidem, Protocole supplementaire, project (no date), p. 2; cf.: letter of R. Andvord to the minister of foreign affairs T. Lie dated 13.09.1945, p. 1.

52 RA, Amb/Leg Warsaw, E.50, G5-A Norske konsulater i Polen, 3.11.1945-15.12.1950, letter of L. Myrebøe to UD, Bergen, 25.07.1945. 
The second phase of Andvord's activities took place in Poland. On September 8 Andvord and Myrebøe came to Warsaw. There the two Norwegians learnt that Z. Wyrozembski, the vice-minister of foreign trade, together with a 17-strong delegation, was going to Stockholm and he also intended to go to Oslo. Andvord quickly notified Raeder, the above mentioned head of Commercial Policy Department, and asked him to get in touch with Wyrozembski and invite him to Oslo. The reaction of the Norwegian MFA was immediate. It was established - via the Norwegian Mission in Stockholm - that a Polish delegation composed of Wyrozembski, Wojciech Chabasiński, trade counsellor in Stockholm, and a secretary (the name unknown) would come to Oslo by plane on Saturday September 22 for one or two days, at the invitation of the Norwegian Government, which would cover all the costs..$^{53}$ It may be said that Andvord was successful again in his struggle to put in motion deliveries of coal to Norway.

In the meantime, Andvord had to focus his efforts on getting approval for the above mentioned projects - the coal contract and the additional protocol - from the Polish. To that end, on September 11 Andvord and Myrebøe went to Katowice, where Andvord presented Myrebøe - as he writes -

to many outstanding people from the Polish coal industry and at the same time had a longer talk with $\mathrm{Mr}$ Gorączko, the general director. We studied the original coal contract of August 22 and compared it with the more detailed one, which I had received from Norsk Brenselimport during my last stay there. ${ }^{54}$

Andvord informs that Gorączko consented to the contents of the suggested coal contract, which was composed of eight paragraphs, with the exception of paragraph four, concerning the distribution of the deliveries of coal according to the individual months. The Norwegians wanted 50,000 tonnes monthly for three months till December 1945, and from January at least 150,000 tonnes monthly, so that the whole supply might end before April 1, 1945. Mr Gorączko's offer was different, starting in October with a small delivery of 30,000 tonnes, in November - 110,000 tonnes, in February - 120,000-140,000 tonnes, and the rest in April. It means that Gorączko from the beginning was aware that it would be impossible

53 RA, UD 1940-1949, Box 11592, 44.4 Handelspolitikk. Allment, 91. Polen, Bd. I 1945/08.05-15.09, three handwritten notes of Raeder dated 13 and 14 IX. in the above mentioned letter, which he received from Andvord.

${ }^{54}$ Ibidem, Letter of Andvord to the minister of foreign affairs of Norway Trygve Lie, Warsaw 13.09.1945, p. 1 . 
to finalise the deliveries till the end of March and that is why he distributed the deliveries in another way, starting with small deliveries and then increasing them; thus he extended the whole supply by one month, i.e. April. As Andvord writes

Gorączko put down all his corrections on the draft of the contract I had brought, he signed each paragraph with the date and took one copy to his files, as if the whole thing had been concluded. We both - Myrebøe and me - came to the conclusion that the purpose of the Polish had been to arrange the deliveries in that way and that they thought it was feasible.

At the end of their stay in Katowice both the Norwegians were invited to dinner by Mr Gorączko, during which he gave a speech underlining the will on the part of the Polish to help Norway in the sphere of coal..$^{55}$

On September 13, when they came back to Warsaw, Andvord went to a meeting with Jędrychowski, Minister of Foreign Trade, and presented the draft of the additional protocol, which he had brought from Oslo. The Polish side suggested some changes, which could not be accepted by Andvord without the consent of his Government, although he personally was prone to do it. In addition to some formal changes consisting in crossing off a few words, paragraph 8 aroused the greatest controversy. The Norwegians wanted to introduce a regulation fixing the end of the mutual deliveries on April 1, 1946, to which the Polish side did not want to consent. The position of the Polish - as Andvord writes in his letter to Trygve Lie, Minister of Foreign Affairs - was motivated by the fact that according to the contract the Polish had to keep delivering the missing quantities of coal still after April 1, 1945. The Polish claimed that the Norwegians could refuse to receive the coal after that date, they also could demand to change the price; hence, it was not necessary to put that date in the additional protocol, all the more - as he underlines in his letter - that

Article 9 of the main contract [of 29 August - E.D.-Sz. ${ }^{56}$, the contents of which we have proposed ourselves to some degree is incompatible with the detailed stipulations of the coal contract concerning deliveries, and when Raeder told me that it was necessary to put paragraph 8 in the additional protocol, I did not discuss any

Ibidem.

56 AAN, Ministry of Treasure II, Ministerstwo Skarbu II, catalogue no. 385, Contract between TRJN of the Republic of Poland and the Royal Government of Norway to regulate merchandise exchange, Warsaw, 29.08.1945, art. 9, k. 4: the Agreement coming into force from the moment of signing. Valid till the mutual obligations have been satisfied. 
longer the need to introduce the changes suggested by the Polish. In spite of all that, both in my opinion and in Myrebøe's this paragraph should be removed without any doubts. ${ }^{57}$

After that clash the Norwegians must have come to the conclusion that sooner or later UD would have to consent to the corrections in the additional protocol, all the more so as they were compatible with the documents signed before, as well as on account of the fact that the contract was to expire after 45 days since the date of signing. Therefore Andvord left the rest of his duties to Myrebøe informing him that he would be given further instructions as soon as possible (in a telegram from UD sent to Moscow, and next in the form of air waybill via the Swedish MFA). He said he was leaving Warsaw for good and the following day -14 September - he was leaving for Moscow.

Soon the matter was solved in the way Andvord wanted. After he arrived in Moscow, on September 18, a telegraphic dispatch was sent to UD from the Norwegian Embassy in Moscow, the contents of which was coincident with what Andvord had included in the above mentioned letter to Trygve Lie, Minister of Foreign Trade, with the exception of the so called clear emphasis on the fact that both Andvord and Myrebøe came to the same conclusion that it was urgent to cross off article 8. In addition to that they recommended other changes in the additional protocol be approved as soon as possible, especially for the reason that the director of the mine in Poland had assured them with his own signature under each of the monthly delivery (from October 1945 to the end of April 1946), the size of which he personally had added to the coal contract. They were included also in this dispatch, which proves that Andvord attached a lot of weight to that element and at the same time he considered the quantities and dates to be feasible. At the end the dispatch says that Andvord recommended Myrebøe be given the authorisation to sign the additional protocol..$^{58}$

Two days later UD sent a telegraphic reply to its Mission in Moscow, in which it in principle consented to the changes introduced in the protocol. According to article 1 UD wanted the credit given by Norges Bank for the purchase of herring

57 RA, UD 1940-1949, Box 11592, 44.4 Handelspolitikk. Allment, 91. Polen, Bd. I 1945/08.05-15.09, Letter of Andvord to the Norwegian minister of foreign affairs Trygve Lie, Warsaw 13.09.1945, p. 2.

58 Ibidem, Box 11592, 44.4 Handelspolitikk. Allment, 91. Polen, Bd. II 1945/16.09-26.09, confidential telegram J. no. 545 II/45 - Melding fra ambassaden i Moskva - Kullavtalen med Polen, p. 1-2. 
and fish oil from Norway to cover the costs of transport of those goods to Poland, too. The next two paragraphs which said that:

the payments to the Norwegian exporters will be made via Norges Bank by bank draft issued by the National Bank of Poland (article 2) and the amounts paid by Norges Bank will be put on the debit side of the account, which will be opened on behalf of the National Bank of Poland (article 3)

were left unchanged. The changes introduced in article 4 were also approved; they concerned the possibility of obtaining dollars by Poland for the quantities of Polish coal that were not offset by the value of the goods delivered by Norway. UD demanded that it be clearly underlined that the first conversion factor will be the Norwegian krone at the rate of 4.97 for a dollar. The costs of transport should be added to the settlement; the costs of transport as well as the accrued interest would be covered by the credit given by Norway. A consent was also given to remove article 8, to establish the final date of delivery on April 1, 1946, because as it had been discussed before - it was incompatible with the contract itself. But UD explained that the intention behind that article was so that both sides after April 1, 1946 could on equal terms discuss the problem of possible later deliveries of the quantities that had not been supplied. ${ }^{59}$

At that moment the question of approving the text of the additional protocol to the contract of August 29, 1945 was concluded. On September 28 UD sent a letter to Lauritz Myrebøe, Consul General, in which once again it depicts all the details of the changes in each of the articles of the draft of the contract, and it mentions the visit to Oslo of two Polish trade representatives, Z. Wyrozembski, Foreign Trade Vice-Minister, and W. Chabasiński, Trade Counsellor. It was a short two-day visit (arrival on Saturday evening October 22 and departure on Tuesday morning October 25), during which they conducted talks with Johann Nore, a Brenselimport director, concerning streamlining the transport of coal from Silesia to the ports. In turn, inside UD a possible increase of the deliveries of fish oil from Norway was discussed. The Norwegians encouraged the Polish representatives with a cheap offer of their merchandise, 2.51 kroner for a kilo of fish oil, underlining that it was the price they sold fish oil to UNRRA, whereas that organisation paid for herring much more than Poland. The difference was

59 Ibidem, Melding til ambassaden i Moskva 20.09.1945. 
about 20 kroner for a barrel of both big and small herring. ${ }^{60}$ It was a signal from UD to Myrebøe, a pro tempore diplomatic representative of Norway in Warsaw, to use that piece of information as a bargaining instrument in further negotiations with the Polish.

On October 3, 1945 Consul L. Myrebøe informs UD that on that day the additional protocol to the Polish-Norwegian Contract of August 29 was signed, and on the part of the Polish it was signed by Stefan Jędrychowski, the Minister of Foreign Trade and Navigation. He adds that before signing the protocol, he discussed the most important question from the point of view of the Norwegians: placing in article 4 the statement that the Polish cannot demand dollars before the value of the coal delivered to Norway, converted into Norwegian kroner, has been offset by the value of the Norwegian goods sent to Poland, including the costs of their transport. He added that he had obtained a confirmation on the part of the Polish Minister, which made the signing of the contract possible.${ }^{61} \mathrm{He}$ explained that he had been acting according to the instructions given by Ambassador Andvord on October $1,1945 .{ }^{62}$ Andvord's arrangements were not unknown in UD, and it was a known fact that he was the author of them. That is why UD, after discussions and minor changes, approved them in the end. Once again it was confirmed how important for the Norwegians Andvord's activity had been; he took care of the contract until the end, although in the last phase he did it from a distance, from Moscow. In two months (August and September 1945) in spite of many obstacles he managed to finalise the two most important questions: securing the deliveries of coal to Norway and finding a place in Warsaw for the Norwegian diplomatic mission, including placing Consul General Lauritz Myrebøe, a pro tempore diplomatic envoy of Norway, in Poland. Those two months of Andvord's struggles was a transitory period, but very important for Norway, to find its place in Central Europe, both from the economic and political point of view. Thanks to the effective efforts of an experienced diplomat, Andvord, Norway broke the traditional dominance of Sweden in the Polish market and fortified its position as an independent political partner, at the same time maintaining perfect relations with its Scandinavian neighbours.

What comes as the biggest surprise is the fact that the Polish side was so little interested in establishing contacts with the Norwegians, leaving many problems

\footnotetext{
60 Ibidem, letter from UD to Myrebøe, the Consul General in Warsaw, 28.09.1945, p. 2.

${ }^{61}$ Ibidem, letter no. 1 of L. Myrebøe to UD, Warsaw 3.10.1945.

62 Ibidem, letter no. 2 of L. Myrebøe to UD, Warsaw 3.10.1945.
} 
concerning Polish matters in the hands of the Swedes. It might be gathered that if it had not been for Ambassador Andvord's presence in Poland, who came to the capital three times during those two months of 1945, Poland would not have sent its diplomatic envoy to Oslo still for a long time and would have held the pre-war option of having the same envoy for both Sweden and Norway. ${ }^{63}$

\subsection{Taking up the Post by Envoy Alfred Danielsen}

On September 20, 1945 UD appointed Alfred Danielsen envoy in Warsaw. Warsaw was to be his working place for the second time. He had come to Warsaw for the first time in January 1920 to hold the post of chargé d'affaires of the Mission in the years 1920-1922. Year 1945 was much more difficult for him as Warsaw was in ruins, and the Polish state was being created in disparate political conditions. Who was Danielsen and why was he charged with that diplomatic mission in Poland?

Alfred Danielsen was born on November 11, 1885 in Riga. His father, Daniel Danielsen (1850-1917) was the owner of a factory in Riga; his mother was Elise Danielsen (1851-1923), née Elmberg in Stavanger. He started university studies in Riga in 1905. In 1909 he finished Bachelor studies of law at the University of Oslo. One year later he was employed as an auxiliary lawyer in Oslo and at the same time as a counsellor for foreign politics in the newspaper 'Verdens Gang'. In the years 1911-1914 he worked as an attorney ad litem for the first three years and in the last year - as a lawyer in the court of justice in Skien. In Autumn 1914 he started a career in UD. Till 1918 he held the post of a UD secretary of the so called second class (one of the four secretaries in UD), ${ }^{64}$ next in the same year he was a pro tempore secretary of the Mission of Norway in Berlin. In 1919 he stayed in France as a scholarship holder, and on January 16, 1920 he was appointed secretary of the Mission and at the same time consul in Warsaw. Danielsen cooperated with Samuel Eyde, a special envoy, Consul General in Poland and a well-known

${ }_{63}$ Archives of the Ministry of Foreign Affairs, Archiwum Ministerstwa Spraw Zagranicznych (henceforth: AMSZ), Z. 6, W. 76, T. 1091, pro domo short note, Warsaw 6.08.1945, k. 1; cf.: note 19. The note is the only document in the Polish archival collections confirming that Andvord was in Poland. It was made by a Br. Wyszyński from the Political Department of the MFA, who confirmed that on August $6 \mathrm{Mr}$ Andvord, the Norwegian Ambassador in Moscow, arrived at the MFA, who complained that since leaving Moscow he had not received any reply to his note on the recognition of TRJN by Norway. In addition, he asked that a Polish envoy be sent to Oslo.

${ }_{64}$ R.Omgang, Norsk utenrikstjeneste, bd. II Stormfulle tider 1913-1928 (Oslo 1959), 220. 
Norwegian entrepreneur. Both gentlemen contributed to establishing good economic and political relations with Poland. Eyde also maintained very good relations with Józef Piłsudski. ${ }^{65}$ In February 1922 he ended his mission in Warsaw, and till 1929 was employed as the head of the Secretariat of UD. In the same year he was sent to the Mission in Moscow, where for six years he was a counsellor. In the years 1935-1943 he was chargé d'affaires in Havana and parallel in the years 1935-1938 in Mexico, after which from 1943 to the end of war he was promoted to the post of envoy in Havana and parallel in two neighbouring islands: Haiti (in Port-au-Prince) and Puerto Rico (in Ciudad Trujillo). In the years 1945-1950 he was appointed envoy in Warsaw and parallel in the years 1947-1948 in Bucharest. Since 1950 he was the head of the Norwegian Military Mission in Berlin and Bonn. He died in Cologne (German: Köln) on April 13, 1952. It may be added that during his first stay in Warsaw he married Astrid Marie Hesselbom (born October 5, 1896). He had two sons, Arne (born on July 8, 1922) and Arild Johann (born on August 22, 1928). ${ }^{66}$

Alfred Danielsen arrived in Warsaw on November 12, 1945, i.e. almost two months after his appointment for the post of envoy in the capital of Poland. After an audience with Bolesław Bierut on the same day when he submitted the letter of accreditation he had a long talk with with Bierut and Modzelewski about the current problems in Norway and in Poland, and afterwards he was driven by the head of the diplomatic protocol Dr Adam Gubrynowicz to the 'Polonia' Hotel. ${ }^{67}$ Ten days later on November 22 he paid a courtesy visit to the Scandinavian Section of the Political Department of the Ministry of Foreign Affairs, where - like Andvord two months earlier - delicately asked Adolf Bryczkowski, head of the above mentioned Section, when a Polish Mission was expected to come to Oslo. The following day at a dinner party to which he had invited A. Bryczkowski in an equally delicate way he dropped a hint to his guest that the Norwegian Government had problems with Polish refugees in Norway. It was about the clashes with the local communities for various reasons, and arrival of a Polish diplomatic

${ }^{65}$ E. Denkiewicz-Szczepaniak, "Józef Piłsudski w norweskiej opinii publicznej - na przykładzie korespondencji posła nadzwyczajnego Królestwa Norwegii w Polsce dr Samuela Eydego", in: Józef Pitsudski wobec Europy i wybranych zagadnień wewnętrznych Drugiej Rzeczypospolitej (1918-1935). W 70.rocznice śmierci, eds. M. Wojciechowski and Z. Karpus (Włocławek-Toruń 2007), 23-33; idem, "Stosunki polityczne i gospodarcze Polski z Norwegią w latach 1918-1926", Zapiski Historyczne LXX (2005) 2-3: 51-75.

${ }^{66}$ Biogram Alfreda Danielsena in: Hvem er hvem? (Oslo: H. Aschehoug \& Co, 1950), 128.

${ }_{67}$ RA, Arkivmateriale hjemsendt fra Amb./Leg.Warsaw, Eske 45, A 7-D 01/45 Sendemann Danielsen, bd. I, letter of Danielsen to UD dated 12.11.1945. 
representative might solve the problem. In addition, Danielsen asked whether it would be an envoy or only chargé d'affaires, suggesting that it would be better to send an envoy. Bryczkowski in his note to Modzelewski underlined that if it was not an envoy it would be chargé d'affaires, but ad interim and for a short time. Bryczkowski expressed a very positive opinion of the Norwegian envoy

Mr Danielsen is a very direct and unpretentious man. His attitude towards Poland is very positive. He declared - undoubtedly - frankly that he was glad that after 20 years he could come back to Poland. He intends to learn Polish and get to know Poland better. ${ }^{68}$

The conditions the Norwegian diplomat was working under were poor, although they were better than the situation of the Danish envoy, who had only one room, which served him as a bedroom and an office. It is worth reminding that Danielsen owed his relatively good situation to Andvord, thanks to whom the envoy and his wife and the auxiliary staff occupied three rooms at the 'Polonia' Hotel (no. 317, $12 \mathrm{~m}^{2}$; no 319, $21 \mathrm{~m}^{2}$; and no 320, $\left.13 \mathrm{~m}^{2}\right)^{69}$. Those rooms served as a place of work and rest. Regular heating was missing and it was a real nuisance, and so were electricity blackouts, and current water was not always available ${ }^{70}$. As far as the auxiliary staff were concerned, still in Autumn 1945 Danielsen employed a Pole, Beata Hłasko ${ }^{71}$ to help him to deal with correspondence in Polish and French, and the chauffeur of the former envoy Niels Ch. Ditleff, Walenty Adamski, who

${ }^{68}$ AMSZ, Z.6, W 76, T. 1091, note of the head of the Scandinavian Department to minister Modzelewski dated 24.11.1945, k. 2.

${ }^{69}$ Two years later Danielsen mentioned it in his letter to UD dated 3.09.1947, RA, Arkivmateriale hjemsendt fra Amb./Leg.Warsaw, E.46, A7-D 1/47, Sendemann Danielsen, bd. II, letter of Danielsen to UD, 309.1947, p. 1.

70 Ibidem, E. 45, A7-D 01/45, Sendemann Danielsen, bd. I, Letter of Danielsen to the director of the 'Polonia' Hotel dated 27.11.1945, in which he asks to put in missing windowpanes in the rooms occupied by the Mission; he also complains about the lack of current water and heating; cf.: letter of Danielsen to UD dated 6 December, 1945, in which he says that the work in the Mission is done in the worst possible office space. Now, when a frost has set in, it happens that the central heating in the hotel does not work during the day. We try to manage somehow using three electrical ovens, but when the electricity disappears for many hours, the fingers become so stiff that it is impossible to separate thin sheets of paper one from the other when we type. We have secured lighting in the form of candles, which we use when the electricity is cut off.

71 Beata Hłasko, née Andrychewicz (born 10.01.1908 in Warsaw, died 9.11.1975 in Warsaw), daughter of a Pole and a Norwegian, translator of Norwegian literature. In the years 1928-1930 she worked in the MFA, 1931-1944 teacher of foreign languages in the Chamber of Industry and Trade in Warsaw. Since 1938 she was married to Maciej Hłasko; an activist of the Home Army, participated in the Warsaw Uprising; in the years 1945-1949 she was a translator in the Norwegian Mission in Warsaw; cf.: https://pl.wikipedia.org/wiki/Beata_H\%C5\%82asko, access 12.07.2018. 
was to be a courier, too. Danielsen had to deal with all types of office work, i.e. opening the incoming correspondence, recording it in a book, writing all the letters in Norwegian, German and English, sealing the correspondence and courier post, encoding and decoding the correspondence, conducting talks with guests, who arrived at the Mission. Therefore, as he states himself, he was active from 7 o'clock in the morning to 8 o'clock in the evening, and that is why he wrote a letter to UD on December 6 asking for a secretary of the Mission to be assigned. ${ }^{72}$ On December 20 UD informed him that on February 1, $1946 \mathrm{Mr}$ Helge Akre had been appointed secretary and he arrived in Warsaw on February 16, 1946. He was a sworn translator of French, and spoke a little bit of Russian. ${ }^{73}$ Danielsen writes that Akre soon learnt the Polish language and also had a skill to negotiate difficult cases on his own', hence he was very useful for the Mission and Danielsen suggested that he should be promoted to the post of counsellor of the Mission of Norway in Warsaw. ${ }^{74}$ And the following year he was, but to the advantage of the Norwegian Mission in Moscow, and not the one in Warsaw.

The above mentioned three rooms of the Mission were to be sufficient for five people, A. Danielsen and his wife Astrid, Secretary Helge Akre, and the two Poles; for the first three they were not only a working place but also private quarters. In the meantime an urgent matter to settle, from the point of view of the interests of the Norwegian merchant fleet, was reaching a full representation of Norwegian consulates in Warsaw and in Gdańsk/Gdynia. On November 27 Danielsen writes to UD about the need to set up consular missions in Poland, in Warsaw and in Gdańsk/Gdyni as soon as possible. As far as the consulate in Warsaw was concerned he proposed Mieczysław Grabiński, a lawyer, for the post of unpaid consul, attaching appropriate certificates from three institutions in Warsaw: the Chamber of Trade and Industry, the Commercial Bank and LOT Polish Airlines, where the above mentioned worked as a lawyer. Danielsen adds that Grabiński has good contacts in the Government, that is why it should not be difficult to get exequatur for him. In turn, for the post of Consul General in

72 UD, Ibidem, letter of Danielsen to UD dated 6.12.1945.

73 UD Arkivmateriale hjemsendt fra Amb/Leg. Warsaw, E. 45, A7-D2/45 Legasjons sekretcer Akre, letter from UD to Den Kgl Legasjon $i$ Warszawa dated 20.12.1945. In the letter there is a short life history of Helge Akre: born in 1903, he worked in the missions in Rio de Janeiro and Tokyo, and in the General Consulate in Shanghai.

74 RA, Arkivmateriale hjemsendt fra Amb. / Leg. Warsaw, Eske 45, A 7-D 01/45 Sendemann Danielsen, bd. I, letter of Danielsen to UD dated 18.12.1946. 
Gdynia he proposes Lauritz Myrebøe, who used to work in WMG for 20 years. ${ }^{75}$ UD replied immediately and positively, and underlined the importance of the Mission in Gdynia/Gdańsk. UD attached a letter from the Mission of Norway in Stockholm, which said that Sweden did not have a representation in Gdańsk, in spite of the fact that the Polish wanted it, which would facilitate the export of coal to Sweden. Therefore it was justified, in the opinion of UD, 'to focus all the attention to appointing a Norwegian consular representative in Gdynia ${ }^{976}$ Yet, the question of the quick nomination of Myrebøe complicates when it turns out that the Polish Government does not recognise the exequaturs issued by the former Polish Governments, all the less the ones issued by the Senate of WMG. Hence, Danielsen advised UD to send as soon as possible a new diploma for Myrebøe as an unpaid Consul General in Gdańsk and Gdynia. He suggested it should be investigated whether Consul Ola Walstad could be recognised by the Polish authorities as Consul General before that matter was settled and the post was taken up by Myrebøe..$^{77}$ Danielsen set about working in contact with the Polish Ministry of Foreign Affairs. As he relates the Polish kept asking him why Norway wanted to send a honorary consul, and he answered that Norway had 600 consulates all over the world, which was motivated by the needs of its merchant fleet. The overwhelming majority of them were unpaid consuls, because on account of a limited budget it was feasible to send only a certain number of paid consuls. Then he was said that 'Poland does not like to issue exequaturs to unpaid consuls, especially when they are citizens of the state that sends them'. Danielsen writes on '...the gentlemen from the Polish MFA asked me to advise UD against using the words "unpaid" or "honorary" in the consuls' diplomas that would be sent to the Polish Government'. ${ }^{78}$ The reaction of UD was immediate, because on December 27 the Mission in Warsaw received a telegram with the information that Myrebøe had been appointed to that post, but at the moment he was ill, hence Ola Walstad would take up the post pro tempore. ${ }^{79}$

75 RA, UD, Amb/Leg Warsaw, E. 50, G 5-A Norske konsulater i Polen 1945 3/11-1950 15/12, letter of Danielsen no. 24 dated 27.11.1945 to UD concerning the consular representation of Norway in Poland.

76 Ibidem, letter from UD no. 30 dated 28.11.1945 to Danielsen, and the attachment - a letter from the Norwegian Mission in Stockholm dated 6.10.1945.

77 Ibidem, letter of Danielsen no. 44 dated 8.12.1945 to UD concerning the free-of-charge General Consulate in Gdańsk and Gdynia.

78 Ibidem, letter of Danielsen no. 47 dated 12.12.1945 to UD.

79 Ibidem, telegram of UD to the Norwegian Mission in Warsaw dated 27.12.1945. 
In that way after the long-lasting negotiations all the matters concerning establishing mutual diplomatic relations between Poland and Norway were finally concluded.

\section{Résumé}

Formally the diplomatic relations between Poland and Norway, taking into consideration the dates of sending both the envoys: the Norwegian one - on November 12, 1945, and the Polish one - on April 6, 1946, were established with a significant difference in time, i.e. five months. A detailed analysis of the archival documentation shows clearly that the Norwegians took the first steps much earlier, on August 30, 1945, sending Rolf Andvord, the Norwegian ambassador in Moscow, to Warsaw in a commercial-diplomatic mission. They took into account both the reality of the Norwegian foreign policy and the different political situation of Poland, as well as the two most important tasks: a fast purchase of coal in Poland and placing their own mission in Warsaw. Andvord carried out the tasks to perfection, which brought greater advantages to Norway than the Norwegians and Andvord himself could have expected. In addition to signing a temporary commercial contract, in which the most important merchandise for the Norwegians was coal, thanks to Andvord the Norwegians obtained relatively good terms for their mission at the 'Polonia' Hotel and established good diplomatic relations with Poland, and the Polish authorities realised they needed a separate diplomatic mission in Norway. From the Polish documentation it clearly appears that the Polish side noticed all that, and Andvord, who was in Modzelewski's good graces, could have worked out that his postulate, repeated two months later by Danielsen, would be fulfilled sooner or later. In the whole thing a significant role was played by Danielsen, who from the very beginning gained respect in the Polish Ministry of Foreign Affairs. A need to establish a separate diplomatic mission in Oslo was fortified in Polish politicians by the desire to eliminate representatives of the Government in Exile in London. For the first months after the end of the war they still had strong influence on the several thousand Poles who lived in Norway and for whom they provided financial assistance. The bargaining card for TRJN was to impel the Poles who had remained in Norway to come back to Poland, although the financial and technical side of the repatriation was left actually in the hands of the Allied Command in Norway. It should be underlined that the endeavours of the Polish Government in Exile were doomed to failure from the start because of 
purely political reasons, in spite of the fact that the London Government decided to maintain the diplomatic mission in Oslo at all costs sending its representatives there. The decisive role in the whole thing was played by the pressure of the Soviet Embassy in Oslo on the Norwegian authorities, as well as by the activities of Mieczysław Rogalski, a pro-Communist envoy of TRJN in Warsaw. It may be claimed that establishing diplomatic relations between Poland and Norway was a kind of clash of two different worlds: the Western one, to which Norway had always belonged, and the Communist one, which in the years 1945-1949 it had only to tolerate.

\section{Bibliography}

\section{Archival Sources}

\section{Riksarkivet Oslo (RA)}

1. Utenriksdepartamentet (UD) 1940-1949.

E. 10 165, 14.21/91 Polens sendemann i Norge.

E. 10 345, 20.20. Fremmede statsborgeres St.Olavs Orden, 91 Polen.

E.10601, 27.5/39B, bind VI, Confidential notes of R. Andvord to the Minister of Foreign

Affairs of Norway and reports of UD to the Norwegian Embassy in Moscow.

E.11 592, 44.4 Handelspolitikk.Allment, 91. Polen:

bd. I. 1945/08.05-15.09.

bd. II. 1945/16.09-26.09.

Arkivmateriale hjemsendt fra Amb./Leg. Warsaw, E. 45, A 7-D 1/45 Sendemann Danielsen, bd. I.

Arkivmateriale hjemsendt fra Amb./Leg. Warsaw, E. 46, A7-D 1/47, Sendemann Danielsen, bd. II.

Arkivmateriale hjemsendt fra Amb/Leg. Warsaw, E. 45, A7-D2/45 Legasjons sekretær Akre

Amb/Leg Warsaw, E. 50, G5-A Norske konsulater i Polen, 3.11.1945-15.12.1950

2. Sosialdepartamentet (Sos.dep.) Sentralarkiv:

E. 0087, mappe 9.1121 Polakker

\section{Archives of the Ministry of Foreign Affairs, Warsaw, Archiwum Ministerstwa} Spraw Zagranicznych, Warszawa (AMSZ):

Z. 6, W.76, Vol. 1090. 
Z. 6, W.76, Vol. 1091.

Z. 6, W.76, Vol. 1092.

Z. 6, W.76, Vol. 1094.

Z. 6, W.76, Vol. 1095.

Z. 6, W.76, Vol. 1096.

Z. 6, W.78, Vol. 1165.

\section{Archives of Modern Files, Warsaw, Archiwum Akt Nowych Warszawa (AAN):}

Ministry of Treasure II, Ministerstwo Skarbu II, catalogue no, Contract between TRJN of the RP and the Royal Government of Norway to regulate merchandise trade, Warsaw, 29.VIII.1945.

\section{Studies}

Andvord R. Med hånden på hjertet. Oslo: Norli, 1964.

Andvord R. (2009). Access 8.03.2018. https://nbl.snl.no/Rolf_Andvord.

Denkiewicz-Szczepaniak E. Norwegia na drodze dylematów i przemian 1945-1949. Toruń: TNT, 1992.

Denkiewicz-Szczepaniak E. "Polsko-norweskie kontakty handlowe w latach 1945-1949". Dzieje Najnowsze XXXVIII (2006), 4: 109-122.

Denkiewicz-Szczepaniak E. "Misja handlowo-dyplomatyczna Rolfa Andvorda w Polsce w sierpniu i wrześniu 1945 roku”. Zapiski Historyczne LXXVII (2012), 3: 23-49.

Denkiewicz-Szczepaniak E. "Józef Piłsudski w norweskiej opinii publicznej - na przykładzie korespondencji posła nadzwyczajnego Królestwa Norwegii w Polsce dr Samuela Eydego. In: Józef Pitsudski wobec Europy $i$ wybranych zagadnień wewnętrznych Drugiej Rzeczypospolitej (1918-1935). W 70. rocznicę śmierci, eds. M. Wojciechowski, Z. Karpus, 23-33. Włocławek-Toruń, 2007.

Gawinecka-Woźniak M. Stosunki rzadu polskiego z rządem norweskim na emigracji w Londynie w latach 1940-1945. Toruń: Druk-Tor, 2008.

Hvem er hvem? Oslo: H.Aschehoug \& Co, 1950.

Hłasko B. Access 12.07.2018. https://pl.wikipedia.org/wiki/Beata_H\%C5\%82asko.

Jussila O., Hentila S., Nevakivi J. Historia polityczna Finlandii 1809-1999. Cracow: Universitas, 2001.

Łossowski P. Historia dyplomacji polskiej, vol. IV (1918-1939). Warsaw: PWN, 1995.

Materski W. Dyplomacja Polski "lubelskiej” lipiec 1944-marzec 1947. Warsaw: Rytm, 2007. 
Neumann W. (1977). Access 4.03.2017. http://www.ipsb.nina.gov.pl/a/biografia/wladyslaw-neuman

Omgang R. Norsk utenrikstjeneste, bd. II Stormfulle tider 1913-1928. Oslo: Gyldendal Norsk Forlag, 1959.

Patek W. Access 4.03.2018. https://encyklopedia.pwn.pl/haslo/Patek-Wieslaw;3954976.html.

\title{
NAWIĄZANIE STOSUNKÓW DYPLOMATYCZNYCH MIĘDZY POLSKĄ A NORWEGIĄ W LATACH 1945-1946
}

\begin{abstract}
Słowa kluczowe: stosunki polsko-norweskie, nawiązanie stosunków dyplomatycznych 1945-1946, działania przedstawicieli polskiego rządu emigracyjnego z Londynu w Norwegii, objęcie poselstwa polskiego w Oslo przez Tymczasowy Rząd Jedności Narodowej, poseł Mieczysław Rogalski - kwiecień 1946 rok, misja Rolfa Andvorda - sierpień-wrzesień 1945 rok, umowa węglowa i nawiązanie stosunków dyplomatycznych z Polską, poseł Alfred Danielsen - listopad 1945 roku
\end{abstract}

\begin{abstract}
Abstrakt
W artykule zaprezentowano proces nawiązywania stosunków dyplomatycznych między Polską a Norwegią po zakończeniu II wojny światowej, co trwało od sierpnia 1945 roku do kwietnia 1946 roku. Artykuł składa się z dwóch zasadniczych części. W pierwszej części przedstawiono wysiłki polskiego rządu emigracyjnego w Londynie zmierzające do utrzymania polskiej placówki dyplomatycznej w swych rękach. Następnie omówiono rozległe działania płk. Tadeusza Tokarza, attaché ds. militarnych Poselstwa RP, akredytowanego przy rządzie norweskim na emigracji w Londynie, związane z różnorodną pomocą dla kilku tysięcy Polaków zgromadzonych w obozach repatriacyjnych na terenie Norwegii, głównie w Moss i Mysen. Na zakończenie tej części wyjaśniono w jaki sposób i dlaczego polskie poselstwo w Oslo zostało przejęte 6 kwietnia 1946 roku przez komunistycznego przedstawiciela Tymczasowego Rządu Jedności Narodowej w Warszawie - Mieczysława Rogalskiego. Opisano także jego pierwsze kontakty dyplomatyczne z władzami norweskimi. W drugiej części szczególną wagę przywiązano do pokazania działań rządu norweskiego, którego zadaniem było, możliwie jak najszybciej, utworzenie własnego przedstawicielstwa dyplomatycznego w Warszawie. Sedno tej części artykułu stanowi centralna rola, jaką odegrał norweski ambasador w Moskwie Rolf Otto Andvord, podczas swej dwumiesięcznej misji w Polsce związanej ze sprawami handlowymi i dyplomatycznymi (08.- -09.1945 r.). Jego zadanie związane było z dwoma konkretnymi kwestiami - podpisaniem umowy z polskimi władzami na szybką dostawę
\end{abstract}


węgla do Norwegii oraz nawiązaniem szybkich i dobrych stosunków dyplomatycznych z Polską. Podkreślono też znaczenie tego, że udało mu się zapewnić 3-pokojowe lokum dla Poselstwa Norwegii w Hotelu Polonia. W końcowej części artykułu zaprezentowano krótki biogram norweskiego posła Alfreda Danielsena, który przybył do Warszawy 12 listopada 1945 roku oraz opisano jego pierwsze dyplomatyczne działania i kontakty z polskimi władzami. 